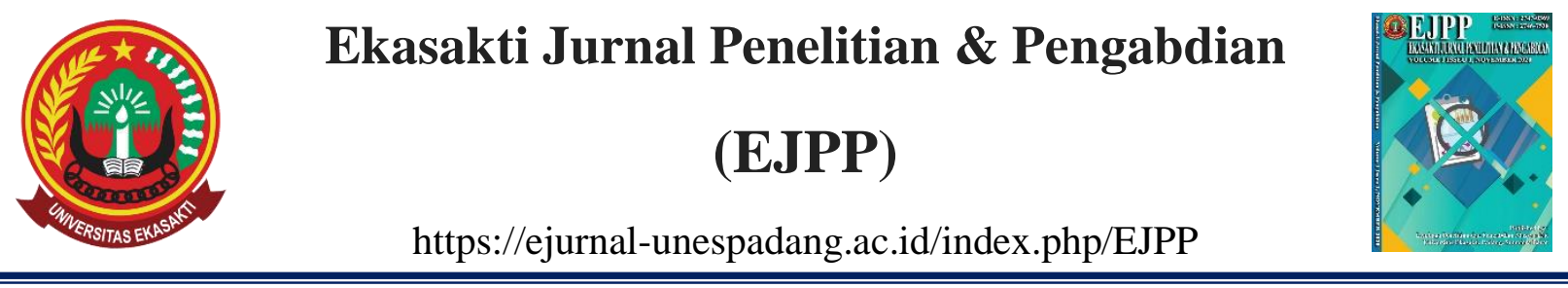

\title{
PELATIHAN AKUNTANSI BAGI USAHA MIKRO KECIL MENENGAH (UMKM) UNTUK MENINGKATKAN KINERJA KEUANGAN USAHA RAKYAT NAGARI TIUMANG, KECAMATAN TIUMANG, KABUPATEN DHARMASRAYA
}

\author{
Gustia Harini $^{1}$, Yesmira Syamra ${ }^{2}$ dan Indra Mulia Pratama ${ }^{3}$ \\ 1) Program Studi Akuntansi, STKIP PGRI Sumatera Barat, Jl. Gunung Pangilun, Padang, 25173 \\ Email: gustia.harini@yahoo.co.id \\ 2) Program Studi Akuntansi, STKIP PGRI Sumatera Barat, J1. Gunung Pangilun, Padang, 25173 \\ Email: mirasyamra@gmail.com \\ ${ }^{3)}$ Program Studi Akuntansi, STKIP PGRI Sumatera Barat, Jl. Gunung Pangilun, Padang, 25173 \\ Email: indramuliap2@gmail.com
}

\section{INFO ARTIKEL}

$\begin{array}{ll}\text { Received } & : 18 / 03 / 2021 \\ \text { Revised } & : 29 / 03 / 2021 \\ \text { Publish } & : 01 / 05 / 2021\end{array}$

Kata Kunci: Akuntansi, Kieneja Keuangan, UMKM.

\begin{abstract}
ABSTRAK
Kegiatan Pengabdian Kepada Masyarakat (PKM) ini berkaitan dengan penggunaan laporan keuangan untuk pelaku usaha masyarakat yaitu pelaku Usaha Mikro Kecil Menengah (UMKM). Peserta pelatian pada pengabdian ini berjumlah 20 orang dari setiap pelaku Usaha Mikro Kecil Menengah (UMKM). Pengabdian ini dilakukan di Kecamatan Tiumang, Kabupaten Dharmasraya. Pengabdian ini bertujuan yaitu memecahkan masalah tentang rendahnya pemahaman anggota UMKM usaha rakyat Nagari Tiumang diKecamatan Tiumang, Kabupaten Dharmasraya. Kegiatan ini dilakukan dengan menggunakan metode ceramah, tanya jawab dan diskusi. Hasil yang diperoleh dari pengabdian masyarakat ini yaitu: (1) Pelaku UMKM Nagari Tiumang Kecamatan Tiumang, Kabupaten Dharmasraya memperoleh pengetahuan dalam penyusunan dan penyajian laporan keuangan usahanya sesuai dengan prinsip dan standar akuntansi yang berlaku umum. (2) Kegiatan pelatihan ini sangat bermanfaat bagi pelaku UMKM Nagari Tiumang Kecamatan Tiumang Kabupaten Dharmasraya dalam meningkatkan kinerja keuangannya sehingga laporan keuangan yang mereka buat sesuai dengan prinsip dan standar akuntansi yang berlaku umum sehingga dapat memberikan informasi bagi pihak pengguna laporan tersebut.
\end{abstract}

Keywords: Accounting, Financial Management, UMKM.

\section{ABSTRACT}

This Community Service Activity (PKM) relates to the use of financial reports for community business actors, namely Micro, Small and Medium Enterprises (MSMEs). The training participants in this service found 20 people from every Micro, Small and Medium Enterprises (MSME) actor. This service is carried out in Tiumang District, Dharmasraya Regency. This service aims to solve the problem of the low understanding of MSME members of Nagari Tiumang 
people's business in Tiumang District, Dharmasraya Regency. This activity is carried out using the lecture method, question and answer, and discussion. The results obtained from this community service are: (1) MSME actors in Nagari Tiumang, Tiumang District, Dharmasraya Regency gain knowledge in preparing and carrying out financial reports in accordance with generally accepted accounting principles and standards. (2) This training activity is very useful for MSME actors in Nagari Tiumang, Tiumang District, Dharmasraya Regency in improving their financial performance so that the financial reports they make are in accordance with generally accepted accounting principles and standards so that they can provide information for the users of the report.

DOI: https://doi.org/10.31933/ejpp.v1i2.318

\section{PENDAHULUAN}

Usaha Mikro Kecil Menengah (UMKM) merupakan salah satu perekonomian Indonesia selain koperasi. Perkembangan jumlah UMKM dari tahun ke tahun semakin bertambah. Secara umum, khususnya dalam aspek finansial, hanya sedikit UMKM yang mengalami perkembangan dalam hal kinerja keuangannya. Hal ini tak lepas dari ketidaksadaran pelaku UMKM terhadap pentingnya pengelolaan keuangan bagi UMKM tersebut khususnya UMKM pada usaha rakyat Nagari Tiumang.

Dalam menjalankan suatu usaha, pengelolaan keuangan menjadi salah satu aspek penting bagi kemajuan usahanya. Pengelolaan keuangan dapat dilakukan melalui akuntansi yang merupakan suatu proses sistematis untuk menghasilkan informasi keuangan yang dapat digunakan dalam pengambilan keputusan bagi penggunanya. UMKM usaha rakyat Nagari Tiumang ini bergerak pada produksi keripik tempe dan lainnya, tetapi mereka masih belum mengerti dalam pembuatan laporan keuangan karena kurangnya pemahaman anggota UMKM usaha rakyat Nagari Tiumang terhadap laporan keuangan serta sebagian besar anggota UMKM usaha rakyat Nagari Tiumang tidak memiliki kompetensi dibidang akuntansi. Salah satu penyebab kesulitannya adalah dalam pembuatan laporan keuangan disebabkan basic pendidikan yang tidak memiliki kompetensi dibidang laporan keuangan.

UMKM usaha rakyat Nagari Tiumang merasa bahwa usaha mereka berjalan normal namun sebenarnya UMKM tersebut tidak mengalami perkembangan. Ketika mereka mendapatkan pertanyaan mengenai laba yang didapatkan setiap periode, mereka tidak bisa menunjukkan berapa laba yang mereka dapatkan. Tidak hanya itu, mereka juga mencatat aset tersebut didapatkan tidak hanya dengan dana usaha tetapi terkadang ditambah dengan harta pribadi. Terkadang selain digunakan untuk perusahaan, aset juga digunakan untuk kepentingan pribadi dan tidak terdapat pencatatan ataupun pemisahan diantara keduanya. Hal ini menyebabkan perkembangan usahanya khususnya dalam hal kinerja keuangan tidak dapat diketahui secara jelas.

Sepanjang UMKM usaha rakyat Nagari Tiumang masih menggunakan uang sebagai alat tukarnya, akuntansi sangat dibutuhkan oleh UMKM tersebut. Akuntansi akan memberikan beberapa manfaat bagi pelaku UMKM, antara lain: (1) UMKM dapat mengetahui kinerja keuangan perusahaan, (2) UMKM dapat mengetahui, memilah, dan membedakan harta perusahaan dan harta pemilik, (3) UMKM dapat mengetahui posisi dana baik sumber maupun penggunaannya, (4) 
UMKM dapat membuat anggaran yang tepat, (5) UMKM dapat menghitung pajak, dan (6) UMKM dapat mengetahui aliran uang tunai selama periode tertentu.

Melihat kenyataan tersebut, perlu diadakan kegiatan pelatihan bagi anggota UMKM usaha rakyat Nagari Tiumang dalam hal mengelola keuangan dengan menggunakan akuntansi. Program pelatihan yang ditawarkan berupa pelatihan akuntansi sederhana. Akuntansi yang diajarkan adalah akuntansi sederhana yang disesuaikan dengan keadaan di UMKM namun tidak meyimpang dari standar dan peraturan yang ada. Adanya pelatihan ini diharapkan anggota UMKM usaha rakyat Nagari Tiumang dapat mengetahui perkembangan usahanya dan dapat memanfaatkan akuntansi guna mendukung kemajuan UMKM mereka. Permasalahan yang dihadapi anggota UMKM kelompok usaha rakyat Nagari Tiumang diKecamatan Tiumang, Kabupaten Dharmasraya diantaranya adalah:

1. Terbatasnya pengetahuan mitra mengenai bagaimana cara mengelola suatu laporan keuangan.

2. Terbatasnya pemahaman mitra untuk mendapatkan pengetahuan mengenai laporan keuangan yang benar.

\section{METODE PENELITIAN}

Metode yang dilakukan dalam kegiatan pengabdian kepada masyarakat ini dilakukan dengan melakukan pendekatan meliputi pendekatan dalam proses penyampaian pengetahuan mengenai pembuatan laporan keuangan sederhana kepada anggota UMKM kelompok usaha rakyat Nagari Tiumang diKecamatanTiumang, Kabupaten Dharmasraya sehingga peserta pengabdian (anggota UMKM kelompok usaha rakyat Nagari Tiumang diKecamatan Tiumang, Kabupaten Dharmasraya) dapat mengetahui tata cara pembuatan laporan keuangan sederhana bagi organisasi yang dilanjutkan dengan pelatihan pembuatannya secara langsung.

\section{Penyampaian Pengetahuan Mengenai Pembuatan Laporan Keuangan Sederhana}

Langkah awal metode pelaksanaan kegiatan pengabdian ini yaitu penyampain pengetahuan mengenai pembuatan laporan keuangan sederhana pada anggota UMKM kelompok usaha rakyat Nagari Tiumang diKecamatan Tiumang, Kabupaten Dharmasraya. Kegiatan ini dilakukan dengan tatap muka secara langsung yang disertai diskusi dan tanya jawab mengenai materi yang disampaiakan.

Adapun materi yang disampaian mengenai pembuatan laporan keuangan sederhana yang meliputi :

\section{Analisis Neraca}

Analisis neraca keuangan ditujukan untuk mengetahui posisi keuangan dari UMKM pada suatu periode tertentu. Neraca merupakan bagian dari laporan keuangan yang dibuat setahun sekali. Neraca memiliki beberapa unsur yang secara garis besar dapat dibagi menjadi tiga meliputi harta, kewajiban dan modal. Melalui analisis neraca ini juga akan bermanfaat bagi peserta sehingga dapat membedakan antaraa harta, kewajiban maupun modal (Hanafi, 2007). 


\section{Analisis Laporan Laba Rugi}

Menurut Kasmir (2012) Analisis Laporan laba rugi merupakan analisis yang memuat laporan tentang selisih pendapatan setelah dikurangi dengan biaya-biaya atau beban. Analisis Laporan Laba Rugi dapat bermanfaat bagi peserta untuk mengambil kebijakan atau sebagai dasar ukuran seperti untuk mengukur tingkat pengembalian dari investasi kegiatan.

3. Analisis Laporan Perubahan Ekuitas

Menurut Jumingan (2006) Laporan perubahan ekuitas adalah laporan yang memuat tentang segala perubahan atau ekuitas untuk suatu periode. Pengetahuan Laporan Perubahan Ekuitas ini sangat bermanfaat bagi peserta sebagai bahan pengetahuan untuk menyusun keuangan keluarga.

\section{Analisis Laporan Arus Kas}

Laporan arus kas memuat segala informasi yang berhubungan dengan kas masuk dan kas keluar dalam periode yang telah ditetapkan. Analisis ini sangat bermanfaat bagi peserta terutama sebagai catatan historis atas pengeluaran atau pemasukan yang berhubungan dengan kas (Sucipto, 2013)

\section{Penerapan Pembuatan Laporan Keuangan Sederhana}

Penerapan pembuatan laporan keuangan sederhana dilakukan dengan metode aplikatif yaitu seluruh peserta diberikan data yang berisi histori pengeluaran, pemasukan, harta dan kewajiban dari laporan keuangan yang belum tersusun secara baik (masih berbentuk data mentah) yang selanjutnya setiap peserta diwajibkan untuk mengelompokkan data tersebut pada 7 buku yang telah disediakan yaitu meliputi : Buku kas, persediaan barang, pembelian barang, penjualan, biaya, piutang maupun buku hutang. Setelah dikelompokkan secara benar, masing-masing peserta diminta untuk menyusunnya kedalam laporan keuangan (laporan laba rugi dan neraca. Kegiatan ini bermanfaat sebagai sarana aplikasi atas pengetahuan yang didapat peserta sehingga peserta diharapkan mampu membuat laporan keuanagan sederhana untuk organisasinya dalam hal ini anggota kelompok usaha rakyat Nagari Tiumang diKecamatan Tiumang, Kabupaten Dharmasraya.

\section{Tahapan Kegiatan Pengabdian}

Kegiatan pengabdian kepada masyarakat ini dimulai dengan melakukan analisis situasi dan koordinasi dengan objek pengabdian kepada masyarakat (anggota UMKM usaha rakyat Nagari Tiumang diKecamatan Tiumang, Kabupaten Dharmasraya), yang dilanjutkan dengan kegiatan inti yang meliputi penyampaian materi mengenai Pembuatan Laporan Keuangan Sederhana yang kemudian diakhiri dengan kegiatan akhir yaitu evaluasi program.

\section{HASIL DAN PEMBAHASAN}

Bagian ini mengemukakan gambaran umum lokasi dan data yang diperoleh selama pelaksanaan kegiatan pengabdian kepada masyarakat (PKM). Kegiatan ini dilakukan dengan menggunakan metode ceramah, tanya jawab dan diskusi. Pengabdian ini dilakukan dalam rangka 
menumbuhkan minat dan kesadaran para pengelola UMKM di Nagari Tiumang di Kecamatan Tiumang Kabupaten Dharmasraya untuk dapat menghitung dan menyusun laporan keuangan berdasarkan prinsip dan standar akuntansi yang berlaku umum sehingga dapat memberikan informasi bagi pihak pengguna laporan tersebut.

\section{Gambaran Umum Lokasi Pelaksanaan}

Pengabdian masyarakat dilaksanakan di nagarai Tiumang Kabupaten Dharmasraya dimana yang menjadi sasaran dalam pengabdian ini adalah para pelaku unit usaha kecil dan menengah (UMKM) di nagari Tiumang.

\section{Peserta Pelatihan}

Pelatihan ini diikuti oleh 20 orang pelaku UMKM dari Nagari Tiumang di Kecamatan Tiumang, Kabupaten Dharmasraya.

\section{Capaian Hasil Kegiatan}

Pada tanggal 26 Februari 2020 telah dilaksanakan kegiatan pengabdian kepada masyarakat berupa Pelatihan Akuntansi Bagi Usaha Mikro Kecil Menengah (UMKM) Nagari Tiumang di Kecamatan Tiumang, Kabupaten Dharmasraya. Usaha yang dilakukan UMKM di nagari Tiumang bergerak pada sektor industri makanan ringan. Perkembangan usaha UMKM usaha rakyat Nagari Tiumang berkembang cukup pesat, dimana hal ini dapat kita lihat dari transaksi yang telah dilakukan UMKM ini dari kegiatan bisnis mereka. Hal yang sangat menarik yang menjadi perhatian tim pengabdian masyarakat program studi pendidikan akuntansi adalah masih kurangnya pemahaman UMKM dalam pengelolaan keuangan yang dapat dilihat masih kurangnya kemampuan pemilik UMKM dalam pembuatan laporan keuangan hal ini tentu akan berdampak terhadap keberlajutan usaha mereka. Dengan adanya program pelatihan yang dilakukan dosen program studi pendidikan akuntansi STKIP PGRI Sumatera Barat yang berupa pelatihan penerapan akuntansi sederhana bagi UMKM dapat meningkatkan kemampuan UMKM dalam mengelola keuangan kegiatan usahanya.

\section{KESIMPULAN}

1. Pelaku UMKM Nagari Tiumang Kecamatan Tiumang, Kabupaten Dharmasraya memperoleh pengetahuan dalam penyusunan dan penyajian laporan keuangan usahanya sesuai dengan prinsip dan standar akuntansi yang berlaku umum.

2. Kegiatan pelatihan ini sangat bermanfaat bagi pelaku UMKM Nagari Tiumang Kecamatan Tiumang Kabupaten Dharmasraya dalam meningkatkan kinerja keuangannya sehingga laporan keuangan yang mereka buat sesuai dengan prinsip dan standar akuntansi yang berlaku umum sehingga dapat memberikan informasi bagi pihak pengguna laporan tersebut. 


\section{REFERENSI}

Hanafi, Mahmud M dan Halim, Abdul. 2007. Analisis Laporan Keuangan Edisi Ketiga. STIE YKPN. Yogyakarta.

Jumingan. 2006. Analisis Laporan Keuangan. Cetakan Pertama. PT. Bumi Aksara. Jakarta.

Kasmir. 2012. Analisis Laporan Keuangan. PT. Raja Grafindo Persada. Jakarta.

Sucipto. 2003. Penilaian Kinerja Keuangan. Jurnal Akuntansi. Program sarjan. Universitas sumatera Utara. Medan. 